
\title{
25 Research Square \\ Effect of Duration of Symptoms on the Clinical and Functional Outcomes of Lumbar Microdiscectomy: A Randomized Controlled Trial
}

Sherwan Hamawandi ( $\nabla$ sherwan.hamawandi@hmu.edu.krd)

College of Medicine, Hawler Medical University, Erbil, Iraq

\section{Research article}

Keywords: Duration of symptoms, Outcomes, Lumbar Microdiscectomy, Oswestry disability index, Roland-Morris Questionnaire, Visual analogue scale

Posted Date: September 28th, 2020

DOI: https://doi.org/10.21203/rs.3.rs-78739/v1

License: (c) (i) This work is licensed under a Creative Commons Attribution 4.0 International License. Read Full License

Version of Record: A version of this preprint was published at Orthopaedic Surgery on December 5th, 2021. See the published version at https://doi.org/10.1111/os.13114. 


\section{Abstract}

Background Microdiscectomy is the gold standard surgical procedure for symptomatic lumbar disc herniation. The aim of this study is to determine whether the preoperative duration of symptoms can affect the postoperative clinical and functional outcomes after microdiscectomy for symptomatic lumbar disc herniation.

Method A single blind, randomized controlled trial was performed by single spine surgeon on patients with symptomatic lumbar disc herniation. 122 patients, who had eligibility criteria, were divided randomly by computer system into 3 groups (A, B and C) who were operated at six weeks, three months and six months from the onset of symptoms respectively. 97 patients were analyzed at the end of this study for outcome measures. Primary outcome measures are Oswestry disability index, Roland-Morris Questionnaire and Visual analogue scale for back pain and leg pain. Secondary outcome measures are post-operative complications, length of hospital stay and time of return to daily activities.

Results Better results among study's groups were in sequence of group A, group B then group C. There was significant difference in Oswestry disability index score until three years of follow up (P-value $<0.001)$. Improvement in Roland-Morris Questionnaire among the groups was significant at three months post-operatively (P-value $<0.001)$. Visual analogue scale for back pain was better significantly at 2 weeks post-operatively ( $P$-value $=0.002$ ) while Visual analogue scale for leg pain was better significantly at 3 months postoperatively ( $P$-value $=0.003$ ). There was no significant difference among study's groups regarding other outcome measures.

Conclusion Preoperative duration of symptoms in patients with lumbar disc herniation can affect the clinical and functional outcomes after microdiscectomy. The shorter duration of symptoms the better postoperative outcomes are. This effect of duration of symptoms on postoperative outcomes is more significant in early postoperative period.

Trial registration NCT, NCT04538027. Registered 1 September 2020 -Retrospectively registered, https://www.clinicaltrials.gov/NCT04538027

\section{Background}

Microscopic lumbar discectomy is a widely used surgical procedure for symptomatic lumbar disc herniation when the conservative management failed. Many studies concluded that Microdiscectomy is now the standard surgical procedure for symptomatic lumbar disc herniation with good to excellent outcomes [1-7].

There are many factors can affect the clinical and functional outcomes after lumbar microdiscectomy as duration of symptoms before surgery. Although, there is no agreement among the previous studies about the certainty of the effect of preoperative duration of symptoms on patients' clinical and functional outcomes after microdiscectomy and absence of randomized controlled trial regarding this issue [8-18]. 
Rushton et al showed, in their systematic review, that "low level evidence supports duration of leg pain pre-operatively not being associated with outcome. The results of prospective observational studies can help clinicians to decide which people should receive surgery or rehabilitation. However, a limitation is that a difference in prognosis does not necessarily mean a causal link with the surgery. Therefore, when we understand the prognostic factors, we need to investigate them in a randomized controlled trial to investigate predictors of treatment response" [15]. For this reason, the current study was made to answer such debate.

The aim of this study is to test the hypothesis of "Can preoperative duration of symptoms affect the clinical and functional outcomes after microdiscectomy for those patients with symptomatic lumbar disc herniation?"

\section{Material And Method \\ Study design}

A randomized controlled trial was done in tertiary spine center by an orthopedic spine surgeon from January 2016 to February 2017 with follow up of three years.

\section{Patients}

150 patients age (19-47) year old were enrolled in this study and assessed for eligibility criteria. 28 patients were excluded from this study because of 17 patients did not meet the inclusion criteria or had exclusion criteria while 11 patients refused to participate in this study. 122 patients entered the randomization program by computer system with allocation 1:1:1 into three groups: group $A$ (41 patients) was treated by lumbar microdiscectomy at six weeks from starting of symptoms, Group B (41 patients) was treated by microdiscectomy at three months from starting of symptoms and Group C (40 patients) was treated by microdiscectomy at six months from starting of symptoms. We had 32 patients in group $A, 30$ patients in group $B$ and 35 patients in group $C$ were analyzed at the end of three years of follow up as shown in study flow diagram (Figure 1).

All patients were assessed by history, physical examination and imaging studies including plain radiographs of the lumbosacral spine, dynamic radiographs with lumbosacral spine in flexion and extension and MRI of lumbosacral spine. Microscopic discectomy was done at six weeks in group A, three months in group $B$ and six months in group $C$. Patients were treated by conservative treatment as changes of life style, medications of non-steroidal anti-inflammatory analgesics, pregabalin and/or gabapentin as well as physiotherapy until the planned time of surgery according to the determined group.

This study was blind by the doctor who assessed the patients for study outcomes pre and postoperatively. 


\section{Inclusion Criteria}

are patients age more than 18 years old and less than 50 years old with symptomatic lumbar disc herniation of either Lumbar 3-Lumbar 4 (L3-L4), Lumbar 4-Lumbar 5 (L4-L5) or Lumbar 5-Sacral 1 (L5-S1) that was proved by Magnetic Resonance Imaging (MRI) to have extruded or sequestrated disc herniation.

\section{Exclusion Criteria}

1/ Spondylolysis or spondylolisthesis.

2/ Spinal deformity like scoliosis.

3/ Previous spinal surgery or infection.

4/ Cauda equina syndrome.

5/ Lumbar segmental instability on dynamic radiograph; translation more than three millimeter (3 $\mathrm{mm})$ or change in angulation more than ten degrees.

6/ Smoking.

7/ Diabetes Mellitus.

8/ Disc herniation other than L3-L4, L4-L5 and L5-S1 levels

9/ More than single level disc herniation.

10/ Body mass index 30 or more than 30 .

11/ Contained disc herniation by MRI.

\section{Outcome measures and follow up}

\section{Primary outcome measures are}

1/ Oswestry disability index (ODI).

2/ Roland-Morris Questionnaire (RMQ).

3/ Visual analogue scale (VAS) for back pain.

4/ Visual analogue scale (VAS) for leg pain. 
All these primary outcome measures were assessed preoperatively and post-operatively at periods of two weeks, three months, six months, one year, two years and three years.

\section{Secondary outcome measures are}

1/ Post-operative complications like dural tear, hematoma, cerebrospinal fluid leak, infection and recurrence of disc herniation within three years of follow up.

2/ Length of hospital stay.

3/ Return to daily activities.

\section{Surgical procedure}

All patients were operated in prone position by using bolsters under chest and pelvis and padding to protect pressure areas. General anesthesia was used in all patients except 6 patients for whom spinal anesthesia was used. A prophylaxis antibiotic (ceftriaxone $1 \mathrm{gm}$ ) about 30 minutes prior to incision. Level of operation was identified using spinal needle and C-Arm fluoroscopy on the symptomatic side. The incision was made from the spinous process of the upper vertebra to the superior margin of the spinous process of the lower vertebra at the involved level. This usually results in 25 to 30 millimeters skin incision. Fascia were incised at the midline. By using appropriate depth of Casper retractor, lamina identified and by using high-speed drill, with microscope, we remove small part of inferior border of superior lamina to allow passing of a blunt hook under the ligamentum flavum so we can open it with a tenotome. A Kerrison rongeur was used to remove the ligamentum flavum and the nerve root was retracted to expose the disc herniation. The herniated disc material was removed and hemostasis was secured and surgical wound was closed in layers without drain.

Post-operative care patients were encouraged to mobilize as early as possible. Stiches were removed after two weeks.

Sample size calculation A formula for sample size calculation was used [19] and it was 30 as a minimal number of patients should be taken in this study so 97 patients was acceptable.

$$
N=\frac{Z^{2} \mathbf{p}(1-\mathbf{p})}{d^{2}}
$$

$\mathrm{N}=$ sample size

$Z=1.96$

$\mathrm{P}=$ the proportion 
$d=$ relative precision $=0.05$

Statistical analysis was carried out using statistical package for social science (SPSS) version 25. Categorical variables were presented as frequencies and percentages. Continuous variables were presented as (Means \pm Standard Deviation). Independent sample t-test was used to compare means between two groups. Analysis of variance (ANOVA) test was used to compare means between three groups. Pearson Chi-square was used to find the association between categorical variables. A Probability of chance value (P-value) of $\leq 0.05$ was considered as significant.

\section{Results}

\section{Demographic data}

In current study 97 patients were analyzed, the mean age of patients was (30.68 \pm 7.30$)$. The younger age was 19 years and the older one was 47 years, males represent (43.3\%) and female represent $(56.7 \%)$. There was no significant difference between means of age between these three groups $(P=0.966)$. There was no significant association between gender and study groups $\left(X^{2}=2.271, P=0.321\right)$. There was no significant association between study's groups and level of disc herniation. $\left(X^{2}=1.88, P=0.756\right)$ as shown in figure 2 .

\section{Regarding primary outcome measures}

The assessments of primary outcome measures of ODI, RMQ and VAS for back pain and leg pain preoperatively and post-operatively among study's groups were shown in table 1 and table 2. 
Table 1

The mean differences of ODI and RMQ among study's groups

\begin{tabular}{|c|c|c|c|c|c|c|c|c|c|c|}
\hline \multirow[t]{2}{*}{ Time } & \multirow[t]{2}{*}{ Group } & \multirow[t]{2}{*}{ No } & \multicolumn{4}{|c|}{ Oswestry disability index } & \multicolumn{4}{|c|}{$\begin{array}{l}\text { Roland-Morris Questionnaire } \\
\text { Improvement }\end{array}$} \\
\hline & & & Mean & SD & F-test & P-value & Mean & SD & F-test & P-value \\
\hline \multirow[t]{3}{*}{2 weeks } & $\begin{array}{l}\text { Group } \\
\text { A }\end{array}$ & 32 & 17.44 & 1.703 & 3.427 & $0.037 *$ & 78.68 & 2.78 & 31.47 & $<0.001 *$ \\
\hline & $\begin{array}{l}\text { Group } \\
\text { B }\end{array}$ & 30 & 18.53 & 1.655 & & & 73.03 & 2.61 & & \\
\hline & $\begin{array}{l}\text { Group } \\
\mathrm{C}\end{array}$ & 35 & 20.74 & 8.486 & & & 65.28 & 10.98 & & \\
\hline \multirow[t]{3}{*}{$\begin{array}{l}3 \\
\text { months }\end{array}$} & $\begin{array}{l}\text { Group } \\
\text { A }\end{array}$ & 32 & 13.19 & 1.595 & 43.73 & $<0.001 *$ & 86.20 & 2.002 & 20.36 & $<0.001 *$ \\
\hline & $\begin{array}{l}\text { Group } \\
\text { B }\end{array}$ & 30 & 15.73 & 1.721 & & & 84.07 & 2.24 & & \\
\hline & $\begin{array}{l}\text { Group } \\
\mathrm{C}\end{array}$ & 35 & 17.26 & 2.005 & & & 80.88 & 4.97 & & \\
\hline \multirow[t]{3}{*}{$\begin{array}{l}6 \\
\text { months }\end{array}$} & $\begin{array}{l}\text { Group } \\
\text { A }\end{array}$ & 32 & 9.88 & 1.431 & 51.66 & $<0.001 *$ & 91.52 & 2.35 & 1.49 & 0.229 \\
\hline & $\begin{array}{l}\text { Group } \\
\text { B }\end{array}$ & 30 & 12.60 & 2.111 & & & 91.25 & 2.40 & & \\
\hline & $\begin{array}{l}\text { Group } \\
\mathrm{C}\end{array}$ & 35 & 14.46 & 1.945 & & & 90.60 & 1.99 & & \\
\hline \multirow[t]{3}{*}{1 year } & $\begin{array}{l}\text { Group } \\
\text { A }\end{array}$ & 32 & 7.94 & 1.390 & 41.83 & $<0.001 *$ & 96.45 & 2.29 & 1.15 & 0.320 \\
\hline & $\begin{array}{l}\text { Group } \\
\text { B }\end{array}$ & 30 & 9.80 & 1.215 & & & 96.82 & 2.50 & & \\
\hline & $\begin{array}{l}\text { Group } \\
\mathrm{C}\end{array}$ & 35 & 11.26 & 1.755 & & & 95.95 & 2.11 & & \\
\hline \multirow[t]{3}{*}{2 years } & $\begin{array}{l}\text { Group } \\
\text { A }\end{array}$ & 32 & 5.38 & 0.942 & 66.08 & $<0.001 *$ & 97.88 & 2.46 & 1.37 & 0.258 \\
\hline & $\begin{array}{l}\text { Group } \\
\text { B }\end{array}$ & 30 & 7.33 & 1.422 & & & 98.09 & 2.57 & & \\
\hline & $\begin{array}{l}\text { Group } \\
\mathrm{C}\end{array}$ & 35 & 8.86 & 1.309 & & & 97.11 & 2.57 & & \\
\hline \multirow[t]{2}{*}{3 years } & $\begin{array}{l}\text { Group } \\
\text { A }\end{array}$ & 32 & 5.00 & 1.016 & 44.43 & $<0.001 *$ & 99.41 & 1.58 & 1.71 & 0.185 \\
\hline & $\begin{array}{l}\text { Group } \\
\text { B }\end{array}$ & 30 & 6.67 & 1.213 & & & 98.78 & 2.26 & & \\
\hline
\end{tabular}




\begin{tabular}{|llllll|} 
Group & 35 & 7.66 & 1.235 & 98.48 & 2.28 \\
C & & & & & \\
\hline
\end{tabular}

No $=$ Number of patients in the group. SD $=$ Standard deviation. Asterix $\left(^{*}\right)$ means statistically significant. 
Table 2

The mean differences of VAS for back pain and leg pain among study's groups

\begin{tabular}{|c|c|c|c|c|c|c|c|c|c|c|}
\hline \multirow[t]{2}{*}{ Time } & \multirow[t]{2}{*}{ Group } & \multirow[t]{2}{*}{ No } & \multicolumn{4}{|c|}{$\begin{array}{l}\text { Visual analogue scale for back } \\
\text { pain }\end{array}$} & \multicolumn{4}{|c|}{ Visual analogue scale for leg pain } \\
\hline & & & Mean & SD & F-test & $\begin{array}{l}\mathrm{P}- \\
\text { value }\end{array}$ & Mean & SD & F-test & P-value \\
\hline \multirow[t]{3}{*}{2 weeks } & $\begin{array}{l}\text { Group } \\
\text { A }\end{array}$ & 32 & 2.34 & 0.483 & 6.901 & $0.002 *$ & 1.56 & 0.504 & 8.993 & $<0.001 *$ \\
\hline & $\begin{array}{l}\text { Group } \\
\text { B }\end{array}$ & 30 & 2.67 & 0.479 & & & 1.87 & 0.346 & & \\
\hline & $\begin{array}{l}\text { Group } \\
\mathrm{C}\end{array}$ & 35 & 2.97 & 0.954 & & & 2.00 & 0.420 & & \\
\hline \multirow[t]{3}{*}{$\begin{array}{l}3 \\
\text { months }\end{array}$} & $\begin{array}{l}\text { Group } \\
\text { A }\end{array}$ & 32 & 1.84 & 0.369 & 2.921 & 0.059 & 1.31 & 0.592 & 6.299 & $0.003^{*}$ \\
\hline & $\begin{array}{l}\text { Group } \\
\text { B }\end{array}$ & 30 & 2.00 & 0.371 & & & 1.63 & 0.490 & & \\
\hline & $\begin{array}{l}\text { Group } \\
\mathrm{C}\end{array}$ & 35 & 2.11 & 0.583 & & & 1.74 & 0.443 & & \\
\hline \multirow[t]{3}{*}{$\begin{array}{l}6 \\
\text { months }\end{array}$} & $\begin{array}{l}\text { Group } \\
\text { A }\end{array}$ & 32 & 0.97 & 0.400 & 0.337 & 0.715 & 0.81 & 0.397 & 0.358 & 0.7 \\
\hline & $\begin{array}{l}\text { Group } \\
\text { B }\end{array}$ & 30 & 1.00 & 0.455 & & & 0.83 & 0.379 & & \\
\hline & $\begin{array}{l}\text { Group } \\
\mathrm{C}\end{array}$ & 35 & 1.06 & 0.482 & & & 0.89 & 0.323 & & \\
\hline \multirow[t]{3}{*}{1 year } & $\begin{array}{l}\text { Group } \\
\text { A }\end{array}$ & 32 & 0.63 & 0.492 & 0.878 & 0.419 & 0.50 & 0.508 & 0.854 & 0.429 \\
\hline & $\begin{array}{l}\text { Group } \\
\text { B }\end{array}$ & 30 & 0.77 & 0.430 & & & 0.60 & 0.498 & & \\
\hline & $\begin{array}{l}\text { Group } \\
\mathrm{C}\end{array}$ & 35 & 0.74 & 0.443 & & & 0.66 & 0.482 & & \\
\hline \multirow[t]{3}{*}{2 years } & $\begin{array}{l}\text { Group } \\
\text { A }\end{array}$ & 32 & 0.38 & 0.492 & 0.591 & 0.556 & 0.38 & 0.492 & 0.235 & 0.791 \\
\hline & $\begin{array}{l}\text { Group } \\
\text { B }\end{array}$ & 30 & 0.50 & 0.509 & & & 0.43 & 0.504 & & \\
\hline & $\begin{array}{l}\text { Group } \\
\mathrm{C}\end{array}$ & 35 & 0.49 & 0.507 & & & 0.46 & 0.505 & & \\
\hline \multirow[t]{2}{*}{3 years } & $\begin{array}{l}\text { Group } \\
\text { A }\end{array}$ & 32 & 0.22 & 0.420 & 0.052 & 0.949 & 0.25 & 0.440 & 0.892 & 0.413 \\
\hline & $\begin{array}{l}\text { Group } \\
\text { B }\end{array}$ & 30 & 0.23 & 0.430 & & & 0.30 & 0.466 & & \\
\hline
\end{tabular}




$\begin{array}{llllll}\text { Group } & 35 & 0.20 & 0.406 & 0.40 & 0.497 \\ \text { C } & & & & & \end{array}$

No $=$ Number of patients in the group. SD $=$ Standard deviation. Asterix $\left(^{*}\right)$ means statistically significant.

\section{Regarding secondary outcome measures}

In group A, one patient got superficial wound infection. In group C, one patient got discitis of L5-S1 level and one patient got Dural tear.

The differences in length of hospital stay and time of return to daily activities were shown in table 3

Table 3

The mean differences of length of hospital stay and return to daily activities among study's groups

\begin{tabular}{|c|c|c|c|c|c|c|}
\hline Study Variables & Group & Number & Mean & $\begin{array}{l}\text { Stander } \\
\text { Deviation }\end{array}$ & F-test & $\begin{array}{l}\mathrm{P} \text { - } \\
\text { value }\end{array}$ \\
\hline \multirow[t]{3}{*}{$\begin{array}{l}\text { Length of hospital stay } \\
\text { (days) }\end{array}$} & $\begin{array}{l}\text { Group } \\
\text { A }\end{array}$ & 32 & 0.53 & 0.507 & \multirow[t]{3}{*}{1.211} & \multirow[t]{3}{*}{0.302} \\
\hline & $\begin{array}{l}\text { Group } \\
\text { B }\end{array}$ & 30 & 0.60 & 0.498 & & \\
\hline & $\begin{array}{l}\text { Group } \\
\text { C }\end{array}$ & 35 & 0.71 & 0.458 & & \\
\hline \multirow[t]{3}{*}{ Return to daily activity (days) } & $\begin{array}{l}\text { Group } \\
\text { A }\end{array}$ & 32 & 2.38 & 0.492 & \multirow[t]{3}{*}{3.039} & \multirow[t]{3}{*}{0.053} \\
\hline & $\begin{array}{l}\text { Group } \\
\text { B }\end{array}$ & 30 & 2.47 & 0.507 & & \\
\hline & $\begin{array}{l}\text { Group } \\
\text { C }\end{array}$ & 35 & 2.71 & 0.710 & & \\
\hline
\end{tabular}

\section{Discussion}

\section{Regarding demographic data}

There was no significant difference among three groups of the study considering age, gender and level of disc herniation; this means that these factors had no effect on the differences in the results among groups of the study.

\section{Regarding primary outcome measures}


There was significant difference in ODI among study groups at 2 weeks, 3 months, 6 months, 1 year, 2 years and 3 years (P-value was 0.037 at 2 weeks and $<0.001$ at other periods of assessments) and we found that the mean of ODI in group $A$ was better than group $B$ and this was better in group $C$ in all periods of assessment which means that early surgical intervention by microdiscectomy can results in better functional outcomes

Group A was better than group $B$ and this was better than group $C$ in postoperative improvements regarding MRQ with significant results in $1^{\text {st }} 3$ months after surgery and that difference among study's groups disappear after 1 year of follow up.

There was significant difference in VAS for back pain among study's groups ( $P$-value $=0.002)$ at 2 weeks, while no significant difference at 3 months of follow up until 3 year, although the means of VAS for back pain were better in group $A$ than group $B$ and least in group $C$ up to 1 year. However, this difference will disappear after 1 year until 3 year of follow up.

There was significant difference among study groups up to 3 months with better results in group $A$ than group $B$ and least in group $C$. This difference remained at 6 months postoperatively but was not significant and disappeared at 1 year to 3 years of follow up.

\section{Regarding secondary outcome measures}

One patient, in group A, got superficial wound infection and was treated by daily dressing and oral antibiotics for 10 days. One patient, in group C, got Dural tear and was controlled by Dural glue. One patient, in group C, got L5-S1 discitis and was treated by parenteral antibiotics for 2 weeks and oral antibiotics for 4 weeks.

There was no statistically significant difference in length of hospital stay and return to daily activities among study's groups. Although, group B had more postoperative hospital stay and more time to return to daily activities than group $A$ and less than group $C$.

\section{Comparison with other studies}

The current study showed better clinical and functional outcomes with early surgical intervention by microdiscectomy as reported by studies of Nygaard et al, Fisher et al, $\mathrm{Ng}$ et al, Omidi-kashani at al, Wankhade et al, Pitsika et al, Ahmadi et al and Basques et al $[8-11,13-14,16,18]$ while study of Shrestha et al [12] showed no significant correlation between duration of symptoms and ODI. Gelalis et al [17] showed no impact of duration of symptoms on clinical outcomes.

Regarding previous studies, none of them was randomized controlled trial and this point makes the importance of current study. 


\section{Limitations of this study}

1/ Relatively small sample size

2/ This study considered only 6 months duration of preoperative symptoms of lumbar disc herniation because of ethical issues we could not delay surgical intervention more than 6 months.

\section{Conclusion}

Preoperative duration of symptoms in patients with lumbar disc herniation can affect the clinical and functional outcomes after microdiscectomy. The shorter duration of symptoms the better postoperative outcomes are. This effect of duration of symptoms on postoperative outcomes is more significant in early postoperative period.

\section{Declarations}

\section{Ethics approval and consent to participate}

The protocol of this clinical study was reviewed and approved by the research ethics committee in Hawler Medical University. Written informed consents to participate were obtained from all patients before study conduction. The guarantee was given for confidentiality of their personal information.

\section{Consent for publication}

'Not Applicable'.

\section{Availability of data and materials}

The datasets used and analyzed during the current study are available from the corresponding author on reasonable request.

\section{Competing interests}

The author declares that he has no competing interests.

\section{Funding}

No funding was received. 


\section{Authors' contributions}

Sherwan.A. Hamawandi was responsible for experiment design, conceptualization, supervision, data collection, manuscript writing and the statistical data analysis.

\section{Acknowledgments}

Great thanks for all people who helped me in my work in this study.

\section{References}

1. Tullberg $T$, Isacson J, Weidenhielm L. Does microscopic removal of lumbar disc herniation lead to better results than the standard procedure? Results of a one-year randomized study. Spine (Phila Pa 1976). 1993;18(1):24-27. doi:10.1097/00007632-199301000-00005

2. Lagarrigue J, Chaynes P. Etude comparative de la chirurgie discale avec et sans microscope. Analyse prospective de 80 cas [Comparative study of disk surgery with or without microscopy. A prospective study of 80 cases]. Neurochirurgie. 1994;40(2):116-120.

3. Findlay GF, Hall BI, Musa BS, Oliveira MD, Fear SC. A 10-year follow-up of the outcome of lumbar microdiscectomy. Spine (Phila Pa 1976). 1998;23(10):1168-1171. doi:10.1097/00007632199805150-00019

4. Thomé $\mathrm{C}$, Barth $\mathrm{M}$, Scharf J, Schmiedek P. Outcome after lumbar sequestrectomy compared with microdiscectomy: a prospective randomized study. J Neurosurg Spine. 2005;2(3):271-278. doi:10.3171/spi.2005.2.3.0271

5. Shriver MF, Xie JJ, Tye EY, et al. Lumbar microdiscectomy complication rates: a systematic review and meta-analysis. Neurosurg Focus. 2015;39(4):E6. doi:10.3171/2015.7.FOCUS15281

6. Feng F, Xu Q, Yan F, et al. Comparison of 7 Surgical Interventions for Lumbar Disc Herniation: A Network Meta-analysis. Pain Physician. 2017;20(6):E863-E871.

7. Hamawandi SA, Sulaiman II, Al-Humairi AK. Open fenestration discectomy versus microscopic fenestration discectomy for lumbar disc herniation: a randomized controlled trial. $B M C$ Musculoskelet Disord. 2020;21(1):384. Published 2020 Jun 15. doi:10.1186/s12891-020-03396-x

8. Nygaard OP, Kloster R, Solberg T. Duration of leg pain as a predictor of outcome after surgery for lumbar disc herniation: a prospective cohort study with 1-year follow up. J Neurosurg. 2000;92(2 Suppl):131-134. doi:10.3171/spi.2000.92.2.0131

9. Fisher C, Noonan V, Bishop P, et al. Outcome evaluation of the operative management of lumbar disc herniation causing sciatica. J Neurosurg. 2004;100(4 Suppl Spine):317-324. doi:10.3171/spi.2004.100.4.0317

10. Ng LC, Sell P. Predictive value of the duration of sciatica for lumbar discectomy. A prospective cohort study. J Bone Joint Surg Br. 2004;86(4):546-549. 
11. Omidi-Kashani F, Ghayem Hasankhani E, Kachooei AR, Rahimi MD, Khanzadeh R. Does duration of preoperative sciatica impact surgical outcomes in patients with lumbar disc herniation?. Neurol Res Int. 2014;2014:565189. doi:10.1155/2014/565189

12. Shrestha D, Shrestha R, Dhoju D, Kayastha S, Jha SC. Study of Clinical Variables Affecting Long Term Outcome after Microdisectomy for Lumbar Disc Herniation. Kathmandu Univ Med J (KUMJ). 2015;13(52):333-340. doi:10.3126/kumj.v13i4.16833

13. Wankhade UG, Umashankar MK, Reddy BS. Functional Outcome of Lumbar Discectomy by Fenestration Technique in Lumbar Disc Prolapse - Return to Work and Relief of Pain. J Clin Diagn Res. 2016;10(3):RC09-RC13. doi:10.7860/JCDR/2016/16607.7512

14. Pitsika M, Thomas E, Shaheen S, Sharma H. Does the duration of symptoms influence outcome in patients with sciatica undergoing micro-discectomy and decompressions?. Spine J. 2016;16(4 Suppl):S21-S25. doi:10.1016/j.spinee.2015.12.097

15. Rushton A, Zoulas K, Powell A, Staal JB. Physical prognostic factors predicting outcome following lumbar discectomy surgery: systematic review and narrative synthesis [published correction appears in BMC Musculoskelet Disord. 2018 Oct 15;19(1):372]. BMC Musculoskelet Disord. 2018;19(1):326. Published 2018 Sep 11. doi:10.1186/s12891-018-2240-2

16. Ahmadi SA, Burkert IP, Steiger HJ, Eicker SO. Multidimensional long-term outcome analysis after single-level lumbar microdiscectomy: a retrospective single-centre study. European Journal of Orthopaedic Surgery \& Traumatology : Orthopedie Traumatologie. 2018 Feb;28(2):189-196. DOI: 10.1007/s00590-017-2043-4.

17. Gelalis ID, Papanastasiou El, Pakos EE, et al. Clinical outcomes after lumbar spine microdiscectomy: a 5-year follow-up prospective study in 100 patients. Eur J Orthop Surg Traumatol. 2019;29(2):321327. doi:10.1007/s00590-018-2359-8

18. Basques BA, Haws BE, Khechen B, et al. The Effect of Preoperative Symptom Duration on Postoperative Outcomes After a Tubular Lumbar Microdiscectomy. Clin Spine Surg. 2019;32(1):E27E30. doi:10.1097/BSD.0000000000000711

19. Daniel W, Cross C. Biostatistics A Foundation for Analysis in the Health Sciences. $10^{\text {th }}$ edition. Wiley. 2013

\section{Figures}




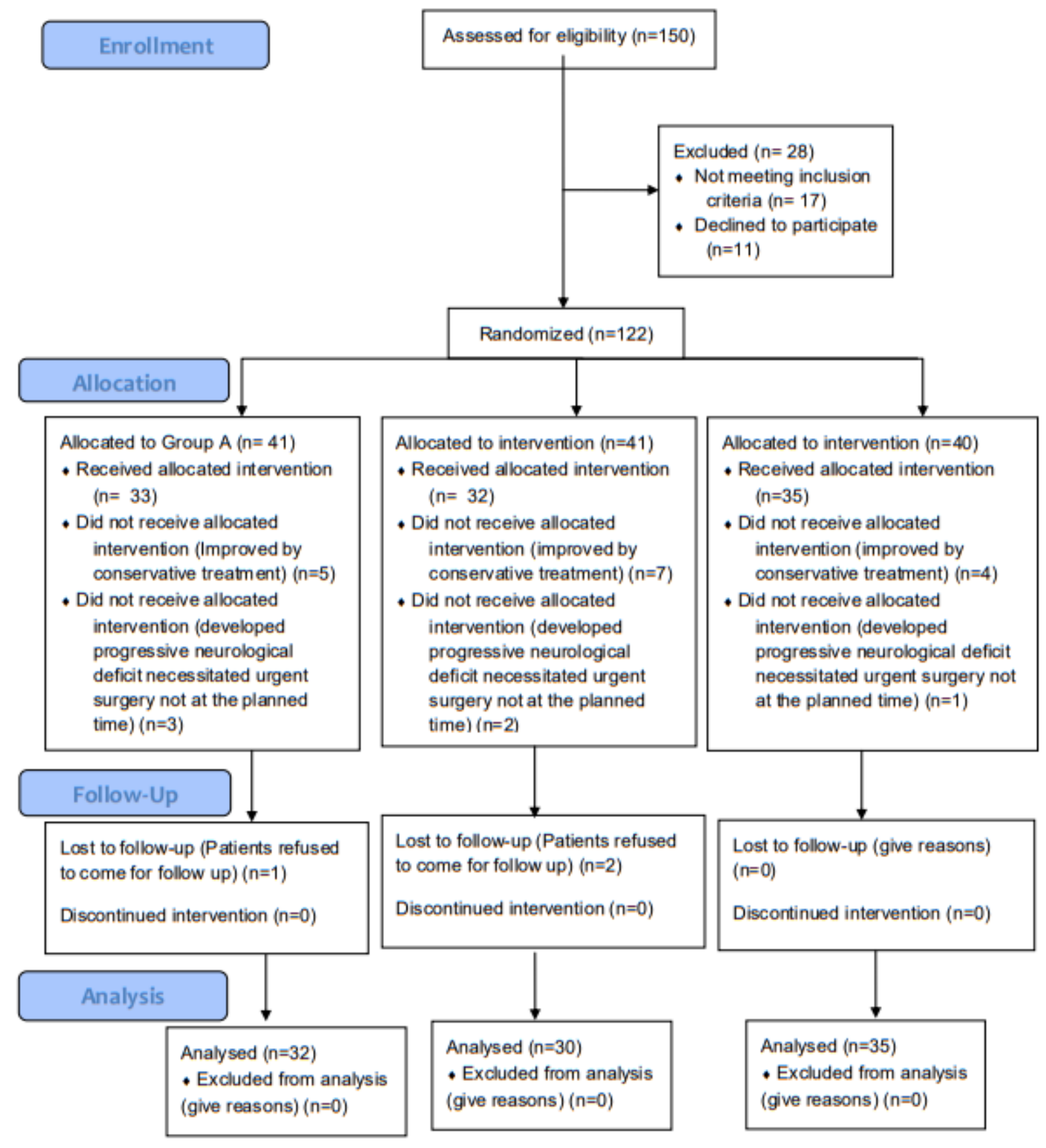

Figure 1

Study flow chart 


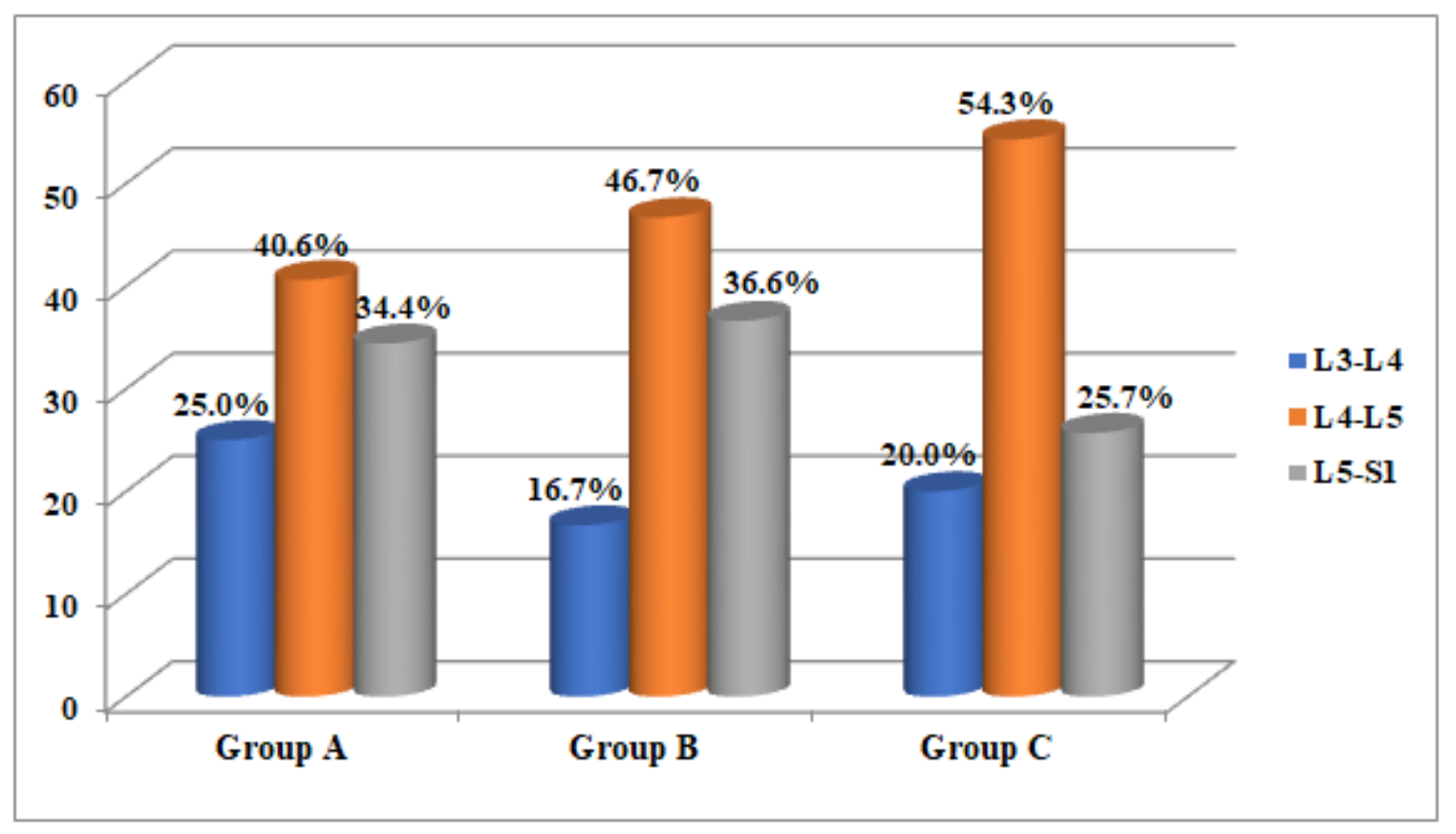

Figure 2

The association between study's group and level of disc herniation

\section{Supplementary Files}

This is a list of supplementary files associated with this preprint. Click to download.

- CONSORT2010ChecklistManuscript5.pdf 